\title{
Spontaneous puberty in girls with early diagnosis of Turner syndrome
}

\author{
Puberdade espontânea em meninas com \\ diagnóstico precoce de síndrome de Turner
}

Stela Carpini', Annelise Barreto Carvalho ',2, Gil Guerra-Júnior, Maria Tereza Matias Baptista ${ }^{1,3}$, Sofia Helena Valente Lemos-Marini' ${ }^{2}$, Andréa Trevas Maciel-Guerra ${ }^{1,4}$

\begin{abstract}
Objective: To verify if the frequency of spontaneous pubertal development among girls with Turner syndrome (TS) diagnosed in infancy and childhood is greater than that of patients diagnosed later. Subjects and methods: Thirty three girls aged $<10$ years at the time of diagnosis were evaluated regarding pubertal development. The frequency of spontaneous puberty was compared with that of girls aged > 13 years diagnosed at the same service. Results: Sixteen of 32 in formative patients had signs of spontaneous puberty, a frequency greater than that of patients diagnosed later. In six patients, there was no progression of puberty; menarche occurred in six, and one became pregnant, but the fetus was a stillborn. Spontaneous puberty was absent in all cases with $45, \mathrm{X}$ karyotype. Conclusions: The greater prevalence of spontaneous puberty in girls whose diagnosis was not based on pubertal delay suggests that, among those diagnosed later, there is a bias towards patients with hypogonadism. Arq Bras Endocrinol Metab. 2012;56(9):653-7
\end{abstract}

Keywords

Turner syndrome; early diagnosis; gonadal dysgenesis; puberty

\section{RESUMO}

Objetivo: Verificar se a frequência de puberdade espontânea em meninas com síndrome deTurner (ST) diagnosticadas na infância é superior a de pacientes diagnosticadas posteriormente. Sujeitos e métodos: Foram avaliadas 33 meninas < 10 anos ao diagnóstico quanto ao desenvolvimento puberal. A frequência de puberdade espontânea foi comparada com a de pacientes com mais de 13 anos diagnosticadas no mesmo serviço. Resultados: Dezesseis das 32 pacientes informativas tiveram sinais puberais espontâneos, frequência superior a daquelas diagnosticadas posteriormente. Em seis delas, não houve progressão da puberdade; a menarca ocorreu em seis casos e uma paciente ficou grávida, porém o feto foi natimorto. Em todos os casos com cariótipo 45,X não ocorreu puberdade espontânea. Conclusões: A maior prevalência de puberdade espontânea em meninas cujo diagnóstico não se baseou em atraso puberal sugere que naquelas detectadas posteriormente haja distorção em favor de pacientes com hipogonadismo. Arq Bras Endocrinol Metab. 2012;56(9):653-7

\section{Descritores}

Síndrome de Turner; diagnóstico precoce; disgenesia gonadal; puberdade
1 Grupo Interdisciplinar de Estudos da Determinação e Diferenciação do Sexo (GIEDDS) Universidade Estadual de Campinas (Unicamp), Campinas, SP, Brazil ${ }^{2}$ Department of Pediatrics, Unicamp, Campinas, SP, Brazil ${ }^{3}$ Department of Internal Medicine, Unicamp, Campinas, SP, Brazil ${ }^{4}$ Department of Medical Genetics, Unicamp, Campinas, SP, Brazil

Correspondence to Andréa Trevas Maciel Guerra Departamento de Genética Médica, Faculdade de Ciências Médicas, Universidade Estadual de Campinas Rua Tessália Vieira de Camargo, 126 13083-887 - Campinas, SP, Brazil atmg@uol.com.br

Received on July/24/2012 Accepted on Sept/3/2012

\section{INTRODUCTION}

$\mathrm{T}$ urner syndrome (TS) is characterized by the presence of an X chromosome and total or partial loss of the second sex chromosome. Cytogenetic findings include the 45 , $\mathrm{X}$ karyotype, and a variety of mosaics and structural sex chromosome abnormalities. The phenotype is highly variable, with various dysmorphic signs, congenital defects of the heart, kidneys and collecting system, as well as autoimmune and endocrine disorders, among others. However, the most frequent findings in TS patients are short stature and primary hypogonadism (1).

In $45, \mathrm{X}$ fetuses, primordial germ cells migrate to the genital ridges, and ovaries develop normally until the $18^{\text {th }}$ 
week of gestation. Afterward, there is an accelerated process of germ-cell loss, which leads to severe impairment of folliculogenesis and increase of connective tissue, ultimately resulting in a contracted fibrous "streak" gonad (2). In TS patients, the diphasic pattern of follicle-stimulating hormone (FSH) and luteinizing hormone ( $\mathrm{LH})$ is similar to that of normal individuals, but gonadotropin concentrations are higher in infancy and in late childhood/adolescence (3). When measured by conventional radioimmunoassay, FSH and LH levels around midchildhood are similar to those of normal children (3); however, gonadotropin levels may be above the normal range when measured by ultrasensitive immunofluorometric or immunochemiluminometric assays $(4,5)$.

Hypergonadotropic hypogonadism was initially considered an invariable feature of TS. In fact, all patients described by Henry Turner (6) had sexual infantilism, and textbooks from the 1960s to the 1980s stated that hypogonadism and sterility were found in almost all cases. Thus, in early studies, diagnosis was more frequently carried out in patients whose clinical features were considered typical by health care professionals in that given moment, such as primary hypogonadism.

In the 1990s, however, researchers recognized that about $21-34 \%$ of girls with TS had adequate circulating estrogen to enter pubertal development. In many of these cases, hormone production could also enable induction of complete secondary sex differentiation and menstruation; afterwards, there could be cessation of menstrual cycles (secondary amenorrhea), or periods could remain regular, allowing these girls to be fertile (7-9).

In 1997, an evaluation of 430 teenage girls with TS revealed that $255(41 \%)$ had some degree of spontaneous pubertal development, and 84 of them (19.5\%) had complete pubertal development and menses (10). As a consequence, sex hormone replacement therapy (HRT) should only be initiated when there are no signs of spontaneous puberty at the age of 12-13 years, and patients show high serum gonadotropins levels $(1,11)$.

There is a predominance of mosaics among this patient population with spontaneous puberty, but this may also be observed in patients with an apparently homogeneous 45,X karyotype (12). Spontaneous fertility may occur in $1.8 \%$ of cases, including those with a $45, \mathrm{X}$ chromosome constitution (12).

Thus, the analysis of studies published in the past decades revealed a progressive increase in the diagnosis of girls with spontaneous puberty, which is certainly due to increased awareness of clinicians to the high phenotypic variability of this syndrome, leading to early diagnosis of cases without a TS stereotype. However, the proportion of cases of TS with spontaneous pubertal development may be even greater, because most studies include patients diagnosed in adolescence or later, when hypogonadism becomes evident. The aim of this study was to verify if the frequency of spontaneous puberty among girls with TS who were diagnosed in infancy and childhood were greater than that observed among girls diagnosed later.

\section{PATIENTS AND METHODS}

Our initial sample comprised 157 girls with TS who were referred to our service for disorders of sex development between 1988 and 2006 (13). Among them, 68 had been diagnosed at 13 years of age or more, and 32 between 10 and 12.99 years of age. Fifty seven had been diagnosed in infancy or childhood, before 10 years of age; 48 of them were followed up thereafter at the University Hospital.

The reason for referral varied with age (Table 1 ). While all girls under 10 years were referred due to short stature and/or TS stigmata, two thirds of those aged 13 years or more were seen because of pubertal delay and/ or primary amenorrhea or secondary amenorrhea, with or without mention of short stature. In the intermediate group (10-12.99 years), short stature and/or TS stigmata were the most frequent reasons, but pubertal delay and/or primary amenorrhea were also mentioned. There were no significant differences regarding karyotype within the three age groups (Table $2 ; \mathrm{p}=0.501$ ).

Table 1. Reason of referral of the 157 girls with Turner syndrome seen at our service between 1988 and 2006, according to the age group

\begin{tabular}{lcccc}
\hline & \multicolumn{4}{c}{ Age at first appointment } \\
\cline { 2 - 5 } Reason for referral & $\begin{array}{c}<\mathbf{1 0} \\
\text { years }\end{array}$ & $\begin{array}{c}\mathbf{1 0 - 1 2 . 9 9} \\
\text { years }\end{array}$ & $\begin{array}{c}\mathbf{2 1 3} \\
\text { years }\end{array}$ & Total \\
\hline TS stigmata & 18 & 1 & 1 & 20 \\
Short stature & 34 & 18 & 15 & 67 \\
$\begin{array}{l}\text { Short stature + TS } \\
\text { stigmata }\end{array}$ & 4 & 6 & 3 & 13 \\
$\begin{array}{l}\text { Pubertal delay and/or } \\
\text { primary amenorrhea }\end{array}$ & 0 & 0 & 12 & 12 \\
$\begin{array}{l}\text { Short stature + pubertal } \\
\text { delay and/or primary }\end{array}$ & & & & \\
amenorrhea & 0 & 5 & 29 & 34 \\
Secondary amenorrhea & 0 & 0 & 4 & 4 \\
Infertility & 0 & 0 & 1 & 1 \\
Not specified & 1 & 2 & 3 & 6 \\
Total & 57 & 32 & 68 & 157 \\
\hline
\end{tabular}


Table 2. Cytogenetic findings of the 157 girls with Turner syndrome seen at our service between 1988 and 2006, according to the age group

\begin{tabular}{lcccc}
\hline \multirow{2}{*}{ Karyotype } & \multicolumn{4}{c}{ Age at first appointment } \\
\cline { 2 - 5 } & $\begin{array}{c}\mathbf{<} \mathbf{1 0} \\
\text { years }\end{array}$ & $\begin{array}{c}\mathbf{1 0 - 1 2 . 9 9} \\
\text { years }\end{array}$ & $\mathbf{2 1 3}$ years & Total \\
\hline $\begin{array}{l}45, X \\
\text { Mosaics without }\end{array}$ & 15 & 5 & 20 & 40 \\
$\begin{array}{l}\text { structural } \\
\text { abnormalities }\end{array}$ & & & & \\
$\begin{array}{l}\text { Structural } \\
\text { abnormalities } \pm \\
\text { mosaicism }\end{array}$ & 18 & 15 & 23 & 56 \\
Total & & & & \\
\hline
\end{tabular}

Fourteen out of the 48 patients diagnosed in infancy or childhood had not reached adolescence in the last appointment in our service ( $<10$ years), and could not be included in the study, as well as a girl who had initiated HRT before the age of ten in another service. Thus, the number of patients included in the study was 33 , all of them followed up by the same team of pediatric endocrinologists. Their ages ranged from 0.1 to 9.87 years at diagnosis, and 14 were diagnosed before 5 years of age. At the time this study was conducted, age range was 10.6 to 28.3 years. Twelve $(36.4 \%)$ had a $45, \mathrm{X}$ karyotype, $11(33.3 \%)$ were $45, \mathrm{X} / 46, \mathrm{XX}$, and $10(30.3 \%)$ had various structural aberrations of sex chromosomes (Table 3). At least 50 metaphases were analyzed from each patient.

The following data were obtained from the patients' medical records: occurrence of signs of spontaneous puberty based on breast development and serum levels of FSH and LH (measured by electrochemiluminescence); and, among patients with spontaneous pubertal development, age at menarche, regularity of menses,

Table 3. Occurrence of spontaneous pubertal development among 32 patients with Turner syndrome diagnosed before the age of 10 , according to chromosome constitution

\begin{tabular}{|c|c|c|c|c|}
\hline \multirow{3}{*}{ Karyotype } & \multicolumn{4}{|c|}{ Spontaneous pubertal development } \\
\hline & \multicolumn{2}{|c|}{ Present } & \multirow[t]{2}{*}{ Absent } & \multirow[t]{2}{*}{ Total } \\
\hline & Complete & Arrested & & \\
\hline $45, X$ & 0 & 0 & 12 & 12 \\
\hline $45, X / 46, X X$ & 9 & 1 & 0 & 10 \\
\hline Structural abnormalities & 1 & 5 & 4 & 10 \\
\hline $45, \mathrm{X} / 46, \mathrm{XX} / 47, \mathrm{XX},+$ mar & 1 & 0 & 0 & 1 \\
\hline $45, X / 46, X X / 46, X, i(X q)$ & 0 & 1 & 0 & 1 \\
\hline $45, X / 46, X,+$ mar & 0 & 2 & 3 & 5 \\
\hline $45, X / 46, X, i(X q)$ & 0 & 1 & 0 & 1 \\
\hline $46, X, i(X q)$ & 0 & 1 & 1 & 2 \\
\hline
\end{tabular}

and occurrence of gestation. Persistent elevated levels of FSH $(>25.8 \mathrm{mIU} / \mathrm{mL})$ and $\mathrm{LH}(>7.7 \mathrm{mIU} / \mathrm{mL})$, and absence of breast development were considered consistent with absence of spontaneous puberty.

Besides a descriptive analysis, the proportion of patients with spontaneous pubertal development in this sample was compared with that observed among patients diagnosed in our service at the same period with more than 13 years of age, when pubertal delay was fully characterized (13). The frequency of spontaneous pubertal development was also compared between girls with a $45, \mathrm{X}$ constitution and other karyotypes, and between those diagnosed before and after 5 years of age. Finally, it was also verified if age at diagnosis (before and after 5 years of age) were similar between $45, \mathrm{X}$ patients and those with other karyotypes. Comparisons were done by Fisher's exact test, and the level of significance was set at 0.05 . The study was approved by the Institutional Review Board, and data from the medical records were collected in 2010.

\section{RESULTS}

Sixteen girls had spontaneous pubertal development, and 16 had absence of pubertal signs associated with high levels of gonadotropins. At the onset of HRT in the latter group, which occurred at a mean age of 12.3 years (range: 10.5 to 14 years), mean levels of FSH and $\mathrm{LH}$ were $128.17 \mathrm{mIU} / \mathrm{mL}$ (range: 67.32 to 201 $\mathrm{mIU} / \mathrm{mL}$ ) and $30.20 \mathrm{mIU} / \mathrm{mL}$ (range: 8.10 to 110 $\mathrm{mIU} / \mathrm{mL}$ ), respectively. Another patient, who had a $45, \mathrm{X} / 46, \mathrm{XX}$ karyotype, had normal serum levels of FSH and $\mathrm{LH}$ (4.26 IU/L and $6.78 \mathrm{IU} / \mathrm{L}$, respectively) in the last appointment at 10.6 years of age, but no signs of spontaneous puberty, and could not be included in either of these groups. Thus, in $50 \%$ of the informative cases $(16 / 32)$, there were signs of spontaneous puberty, a frequency significantly greater than that found in the group of patients with more than 13 years of age diagnosed at our service in the same period $(18 / 63$ or $28.6 \%$; $\mathrm{p}=0.039)(13)$.

In $6 / 16$ girls with spontaneous pubertal development, there was no progression of puberty. They presented only breast development (until Tanner breast stage 2 - B2 - in three cases, B 3 in two, and B4 in one case), and subsequent clinical and hormonal evidence of ovarian failure led to the institution of HRT, which occurred at a mean age of 13.7 years (range: 12.4 to 15.5 years). Menarche occurred in six of the remaining 
ten patients, with a mean age of 13.7 years (range: 12.0 to 15.8 years); the other four patients were aged 12.4 to 14.0 years in the last appointment.

Among those who had menses, whose ages in the last appointment ranged from 14.4 to 23.1 years (mean: 18.2 years), there were no cases of secondary amenorrhea or irregular menstrual cycles. One of the girls became pregnant at 24 years of age. Intrauterine growth restriction was detected in the second trimester of pregnancy and, at 26 weeks of gestation, the fetus died in utero. The fetal karyotype was $46, \mathrm{XY}$, and no post-mortem examination was carried out.

Within the group of 32 informative patients, none of the 12 girls with a 45 , X karyotype had spontaneous pubertal development. On the other hand, spontaneous pubertal signs were found in 16 of the 20 patients with other chromosome constitutions $(\mathrm{p}<0.001)$, including all ten girls with a $45, \mathrm{X} / 46, \mathrm{XX}$ karyotype. The percentage of the $45, \mathrm{X}$ cell line in the cases with a $45, \mathrm{X} / 46$,XX karyotype ranged from $4 \%$ (two cases) to $70 \%$ (one case) (mean: $20 \%$ ). Among ten patients with structural aberrations, six had spontaneous pubertal development, including two patients with a mosaic $46, \mathrm{XX}$ cell line. Within the six patients with arrested puberty, five had structural sex chromosome aberrations, and only one had a 45,X/46,XX karyotype (Table 3 ).

Though not significant, the frequency of spontaneous pubertal development was lower among girls diagnosed before 5 years of age $(4 / 14)$ than among those diagnosed between 5 and 10 years $(12 / 18 ; \mathrm{p}=$ $0.073)$. In addition, patients diagnosed before 5 years of age had more frequently a $45, \mathrm{X}$ karyotype $(8 / 14)$ than those diagnosed between 5 and 10 years $(4 / 18$; $\mathrm{p}=0.068$ ).

\section{DISCUSSION}

Although infertility is an important challenge affecting girls and women with TS, sexual development is also a sensitive issue, particularly during adolescence (14). The finding of a significantly greater frequency of spontaneous pubertal development in girls diagnosed before the age of 10 who were not diagnosed based on pubertal delay suggests that, among those with late diagnosis (more than 13 years old), the search for medical attention due to absence of breast development and primary amenorrhea leads to a bias in the estimate of the proportion of cases with spontaneous pubertal signs. Thus, although the relatively small number of patients in this sample may limit the power of the study, the frequency of spontaneous pubertal development in TS may be even greater than currently estimated.

However, spontaneous pubertal development may be arrested in any of its stages, including lack of progression of breast development associated with high levels of gonadotropins, as occurred with six of the 16 patients, or secondary amenorrhea, which did not occur in this sample, maybe because there were no patients aged more than 23.1 years at the time this study was conducted. In this sample, some girls did not reach Tanner stage 3 of breast development, while others reached stage 5 and had regular menses, and one of them became pregnant, demonstrating the variability of the residual ovarian function.

Our results also show that the presence of a 46 , XX cell line confers a high probability of spontaneous pubertal development, as previously reported $(10,15,16)$, indicating that the karyotype of infants and children with TS is relevant regarding future prognosis of gonadal function and fertility. On the other hand, all girls with a 45,X karyotype had totally induced puberty, different from other studies, in which spontaneous pubertal development was found in up to $14 \%$ of these cases $(10,15)$. This may be due to the greater number of cells analyzed in this study (at least 50), which distinguishes the present study from other ones on this matter, and enables the diagnosis of low frequency mosaicism (17).

The fact that patients with the 45,X karyotype are diagnosed earlier than those with other karyotypes has already been observed (18). In addition, significantly greater values of FSH have been observed in young $45, \mathrm{X}$ patients when compared with those with $45, \mathrm{X} / 46, \mathrm{XX}$ mosaicism (16). Thus, in spite of the greater frequency of spontaneous pubertal development among girls diagnosed in our service between 5 and 10 years of age, and the greater frequency of non- $45, \mathrm{X}$ patients in this age group not reaching significance, one may speculate that girls diagnosed in mid-childhood, usually during investigation of short stature, have the highest probability of having spontaneous pubertal development. In these cases, the levels of anti-Müllerian hormone (AMH) seem to be a promising marker of the remaining ovarian function (19).

In conclusion, although it has generally been assumed that absence of spontaneous puberty is an almost inevitable feature of TS, practitioners must be aware that there is, in fact, a high frequency of spon- 
taneous pubertal development in TS patients in order to prevent them from overlooking this condition in girls with short stature and/or other features of TS, but without hypogonadism. Additionally, the possibility of spontaneous puberty and fertility may not be ruled out when the diagnosis is carried out in infancy or childhood, particularly in the presence of a $46, \mathrm{XX}$ cell line.

Acknowledgments: this study was supported by Programa Institucional de Bolsas de Iniciação Científica/The National Council for Scientific and Technological Development (PIBIC/CNPq), Brazil (quota 1/8/2009-31/7/2010).

Disclosure: no potential conflict of interest relevant to this article was reported.

\section{REFERENCES}

1. Bondy CA. Turner syndrome study group. Care of girls and women with Turner syndrome: a guideline of the Turner Syndrome Study Group. J Clin Endocrinol Metab. 2007;92(1):10-25.

2. Reynaud K, Cortvrindt R, Verlinde F, De Schepper J, Bourgain C, Smitz J. Number of ovarian follicles in human fetuses with the 45,X karyotype. Fertil Steril. 2004;81(4):1112-9.

3. Conte FA, Grumbach MM, Kaplan SL. A diphasic pattern of gonadotropin secretion in patients with the syndrome of gonadal dysgenesis. J Clin Endocrinol Metab. 1975;40(4):670-4.

4. Ropelato MG, Escobar ME, Gottlieb S, Bergada C. Gonadotropin secretion in prepubertal normal and agonadal children evaluated by ultrasensitive time-resolved immunofluorometric assays. Horm Res. 1997;48(4):164-72.

5. Chrysis D, Spiliotis BE, Stene M, Cacciari E, Davenport ML. Gonadotropin secretion in girls with Turner syndrome measured by an ultrasensitive immunochemiluminometric assay. Horm Res. 2006;65(5):261-6.

6. Turner HH. A syndrome of infantilism, congenital webbed neck and cubitus valgus. Endocrinology 1938;23:566-74.

7. Lippe B, Westra SJ, Boechat MI. Ovarian function in Turner syndrome: recognizing the spectrum. In: Hibi I, Takano K, editors.
Basic and clinical approach to Turner syndrome. Amsterdam, NL: Elsevier Science Publishers; 1993. p. 117-22.

8. Price DA, Albertsson-Wikland K. Demography, auxology and response to recombinant human growth hormone treatment in girls with Turner's syndrome in the Kabi Pharmacia International growth study. Acta Paediatr. 1993;82(s391):69-74.

9. Lippe B. Turner syndrome. In: Sperling MA, editor. Pediatric Endocrinology. Philadelphia, USA:WB Saunders; 1996. p. 387-422.

10. Pasquino AM, Passeri F, Pucarelli I, Segni M, Municchi G. Italian's Study Group for Turner's syndrome. Spontaneous pubertal development in Turner's syndrome. J Clin Endocrinol Metab. 1997;82(6):1810-3.

11. Hjerrild $\mathrm{BE}$, Mortensen $\mathrm{KH}$, Gravholt $\mathrm{CH}$. Turner syndrome and clinical treatment. Br Med Bull. 2008;86:77-93.

12. Hadnott TN, Gould HN, Gharib AM, Bondy CA. Outcomes of spontaneous and assisted pregnancies in Turner syndrome: the U.S. National Institutes of Health experience. Fertil Steril. 2011;95(7):2251-6.

13. Carvalho AB, Guerra-Junior G, Baptista MTM, Marques-de-Faria AP, Lemos-Marini SH, Maciel-Guerra AT. Turner syndrome: a pediatric diagnosis frequently made by non-pediatricians. J Pediatr (Rio J). 2010;86(2):121-5.

14. Sutton EJ, Mclnerney-Leo A, Bondy CA, Gollust SE, King D, Biesecker $B$. Turner syndrome: four challenges across the lifespan. Am J Med Genet A. 2005;139A(2):57-66.

15. Hagen CP, Main KM, Kjaergaard S, Juul A. FSH, LH, inhibin B and estradiol levels in Turner syndrome depend on age and karyotype: longitudinal study of 70 Turner girls with or without spontaneous puberty. Hum Reprod. 2010;25(12):3134-41.

16. Fechner PY, Davenport ML, Qualy RL, Ross JL, Gunther DF, Eugster EA, et al. Differences in follicle-stimulating hormone secretion between 45,X monosomy Turner syndrome and 45,X/46,XX mosaicism are evident at an early age. J Clin Endocrinol Metab. 2006;91(12):4896-902.

17. Hook EB. Exclusion of chromosome mosaicism: tables of 90 percent, 95 percent and 99 percent confidence limits and comments on use. Am J Hum Genet. 1977;29:94-7.

18. Massa G, Verlinde F, De Schepper J, Thomas M, Bourguignon JP, Craen $\mathrm{M}$, et al. Trends in age at diagnosis of Turner syndrome. Arch Dis Child. 2005;90(3):267-8.

19. Hagen CP, Aksglaede L, Sørensen K, Main KM, Boas M, Cleemann L, et al. Serum levels of anti-Müllerian hormone as a marker of ovarian function in 926 healthy females from birth to adulthood and in 172Turner syndrome patients. J Clin Endocrinol Metab. 2012;95(11):5003-10. 